\title{
Racialized, Gendered, and Sensationalized: An examination of Canadian anti-trafficking laws, their enforcement, and their (re)presentation
}

Hayli Millar (D) and Tamara O’Doherty

\begin{abstract}
In Canada, there are persistent allegations and some empirical evidence suggesting racialized police bias; certain (non-White) groups appear to face over-enforcement as criminal suspects and under-enforcement as victims. Yet, it is challenging to prove or disprove these claims. Unlike other countries, where governments routinely publish police-reported crime and criminal court data identifying the race/ethnicity of criminal suspects and victims, Canada maintains a ban on the publication of such data. In this article, using an intersectional and critical analysis, we examine 127 prosecuted (predominantly domestic sex) trafficking cases and explore related claims of racial and gender bias together with sensationalism in the enforcement of Canadian anti-trafficking in persons laws. Our findings align with other empirical research observing the racially selective identification and prosecution of sex trafficking cases through a heteronormative and gender binary lens. Whether real or perceived, racial-alongside gender, sexuality, economic, citizenship, and occupational-bias has significant adverse consequences for the equality, liberty, security, mobility, labour, and access to justice rights of the Indigenous, Black, Arab/Muslim and other racialized communities being policed. Our data reveal a clear and pressing need to publish race-disaggregated crime and criminal court data and to challenge deeply ingrained stereotypes using various means.
\end{abstract}

Keywords: trafficking in persons, access to justice, criminalization and racialization, racially selective policing and prosecution, sex work, law and policy

\section{Résumé}

Au Canada, il y a des allégations persistantes et des preuves empiriques suggérant des préjugés racistes de la part de la police; certains groupes (non blancs) semblent être confrontés à une application excessive de la loi comme suspects et à une application insuffisante comme victimes. Pourtant, il est difficile de prouver ou de réfuter ces allégations. Contrairement à d'autres pays, où les gouvernements publient régulièrement les données de la police et des tribunaux pénaux identifiant la race/ethnicité des suspects et des victimes, le Canada maintient une interdiction de publication de ces données. Dans cet article, à l'aide d'une analyse intersectionnelle et critique, nous examinons 127 cas de trafic (principalement le trafic sexuel en 
territoire national) ayant fait l'objet de poursuites judiciaires et explorons les allégations connexes de préjugés raciaux et sexuels, ainsi que le sensationnalisme dans l'application des lois canadiennes contre la traite des personnes. Nos conclusions s'alignent sur d'autres recherches empiriques observant l'identification et la poursuite raciales sélectives des cas de trafic sexuel à travers une lentille binaire hétéronormative et sexospécifique. Qu'elle soit réelle ou perçue comme telle, la race - à côté du sexe, de la sexualité, de l'économie, de la citoyenneté et des préjugés professionnels - a des conséquences négatives importantes sur l'égalité, la liberté, la sécurité, la mobilité, le travail et les droits d'accès à la justice des communautés autochtones, noires, arabes/musulmanes et autres communautés racialisées qui sont contrôlées par la police. Nos données révèlent un besoin clair et urgent de publier des données sur la criminalité et les tribunaux pénaux ventilées par race et de remettre en question des stéréotypes profondément ancrés.

Mots clés : traite des personnes, accès à la justice, criminalisation et racialisation, police et poursuites sélectives sur le plan racial, travail du sexe, loi et politiques.

\section{Introduction}

Long-standing allegations and a growing body of legal and empirical evidence suggest there is racialized ${ }^{1}$ police bias and systemic racism within the Canadian criminal justice system resulting in over-enforcement against certain groups as criminal suspects, especially Indigenous and Black persons, and underenforcement regarding victimization of these same groups (British Columbia Civil Liberties Association (BCCLA) 2010; Gittens and Cole 1995; Jiwani 2016; Lewis 1992; Maynard 2017; McNeilly 2018, 2019; Monchalin 2010; Ontario Human Rights Commission (OHRC) 2003, 2017, 2018; $R$ v Barton (2019); $R$ v Le (2019); $R v$ Spence (2005); $R v$ Williams (1998); Sinclair 2018; Tanovich 2008; Tulloch 2018; Union of BC Indian Chiefs and BCCLA 2018; Wortley 2019). Other scholars have documented discriminatory criminal justice practices and a troubling rise in the racial profiling of Arab, Muslim, and South Asian criminal suspects post-9/11 (Bahdi 2003; Foster, Jacobs and Siu 2016; Nagra and Maurutto 2016; Pratt and

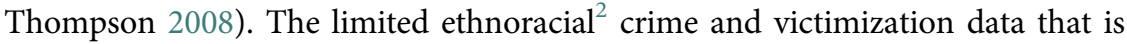
publicly available mainly concern Indigenous persons or are typically in aggregate form (e.g., categorizing "visible minorities" as a single group). However, due to a de facto ban on publication of the race/ethnicity of criminal suspects and victims - and what appears to be the deliberate suppression of the publication of such data by

1 We draw on Jiwani's (2016) use of the terms "criminalization," "racialization," and the "racialization of crime" to refer to socially constructed processes whereby a dominant group (in this case, White European Canadians) use their political and economic power to systematically associate the perceived and presumed differences of particular population groups (Indigenous persons, Black and other persons of colour, non-citizens, immigrants) with negatively valued characteristics and behaviours, resulting in their over-policing and overrepresentation in the criminal justice system.

2 We use the term "ethnoracial" to reflect the Canadian government's reluctance to use the term "race" and its preference for "ethnicity," ostensibly to disguise basic racial power relations in society (Owusu-Bempah and Wortley 2014). Canada identifies three main population groups: Aboriginal or Indigenous persons, Caucasians, and the contentious category of "Visible Minorities," which the federal Employment Equity Act (section 3) defines as persons who are "non-Indigenous and nonCaucasian in race or non-White in colour." 
Canadian police agencies-it is exceptionally challenging to prove or disprove claims about real or perceived racial bias in Canadian law enforcement and the administration of criminal justice (Foster and Jacobs 2017; Millar and OwusuBempah 2011; Mosher and Mahon-Haft 2010; Owusu-Bempah and Wortley 2014; Reasons et al. 2016; UN Committee on the Elimination of Racial Discrimination 2017; UN Working Group on Persons of African Descent 2016/2017). ${ }^{3}$

In the absence of nationally produced and publicly accessible ethnoracialdisaggregated crime and victimization data across the criminal justice process, and given a lengthy history of embedded gendered and racialized differences in international and national laws regulating "prostitution" ${ }^{4}$ and trafficking in persons (see, e.g., Balgamwalla 2016; Bernstein 2010; Doezema 2010; Gallagher 2010; Kaye 2017; Kempadoo 2005; Raguparan 2019; Weitzer 2011), we sought to critically analyze perceptions of racial and gender bias and sensationalism in the enforcement and prosecution of contemporary Canadian anti-trafficking and anti-prostitution laws by examining 127 prosecuted trafficking $(N=87)$ and commodification and prostitution $(N=40)$ cases. We include comparative data on both anti-trafficking and antiprostitution laws while rejecting the conflation of human trafficking and sex work.

Our intersectional analysis of 127 prosecuted cases provides tentative empirical support for the apparent racialized, gendered, and sensationalistic portrayal of the enforcement of anti-trafficking laws. Our findings affirm our earlier research that Canadian laws and law enforcement efforts follow a largely reductive narrative that erroneously treats sex work as synonymous with trafficking in persons irrespective of individual agency or consent (Millar and O’Doherty 2015). Our findings also reveal a prevailing stereotype of a (racially threatening, male) villain, an iconic (visible and deserving White) female who is an unwitting victim, a (predominantly White) criminal justice system, and White victim advocates as benevolent rescuers that have been similarly identified for other countries (see, e.g., Faulkner 2018; Kinney 2015; O’Brien 2016; Shih 2016; Soderlund 2005; Srikantiah 2007). These findings suggest the need to challenge whether the Canadian criminal justice system effectively "protects" the safety and security interests of racialized and marginalized groups, especially migrant, Indigenous and Black sex workers; indeed, it appears virtually impossible for the state to continue down its path of targeted criminalization and meet its parallel international and domestic legal commitments to ensure a range of protected human rights and freedoms, including equitable access to justice.

\section{The Evolving Canadian Anti-Trafficking Legal Context}

Our data was collected at a vital moment for criminal law reform: the 2013 unanimous Supreme Court of Canada decision to uphold the safety and security rights of sex workers by striking down the criminal prohibitions against publicly

See especially Owusu-Bempah and Millar (2010:97-100) on the origins of the de facto publication ban on race-disaggregated crime data in the early 1990 s.

4 We use the terms, "human trafficking" and "trafficking in persons" interchangeably. Given the associated stigma, we reluctantly use the terms "prostitute" and "prostitution" to align with dominant legal, political, and media discourses. Where possible, we use the alternatives sex worker and sex work. 
selling sexual services, operating a brothel, and living on the avails of prostitution (Canada (Attorney General) v Bedford 2013). This landmark decision was quickly supplanted by the Conservative government's enactment of an ostensibly asymmetric (end-demand) system of law criminalizing the purchase of sexual services, third-party involvement, and third-party advertising in commercial sex work, among other prohibitions (the Protection of Communities and Exploited Persons Act 2014; hereinafter PCEPA). ${ }^{5}$ This highly controversial law reinstated many of the criminal prohibitions that were declared unconstitutional in Bedford while increasing criminalization and altering the declared objective of criminalization. The PCEPA demarcates a paradigmatic shift away from regarding commercial sex work as a public nuisance to viewing sex work as a form of exploitation disproportionately affecting (cisgender and straight) women and girls who are assumed to be passive victims in need of state protection and assistance to "exit" the sex sector. The PCEPA increased the severity of new and re-enacted prohibitions, along with their minimum and maximum penalties, some of which appear to be implicitly gender biased. ${ }^{6}$ The PCEPA also added subsidiary human trafficking offences and increased the severity of their penalties. There is significant overlap in the phrasing and elements of some of the new commodification offences and the criminal trafficking in persons offences, which is troubling given the prospects for overcharging and multiple convictions for essentially the same offence.

In Canada, the conflation of human trafficking and prostitution and a consequential reductive narrative that trafficking is mostly, if not entirely, related to sexual exploitation, serves to invisibilize the multiplicity of other forms of trafficking, including same-sex and gender non-binary sex trafficking and a range of other labour and human rights violations, other forms of exploitation, and forced labour. ${ }^{7}$ This unidimensional (re)presentation of trafficking is evidenced in many ways, including the enactment and amendment of criminal anti-trafficking laws and the jurisprudence interpreting and applying those laws; anti-trafficking policies, especially the National Action Plan to Combat Human Trafficking (Public Safety Canada 2012) and recently released \$75 million National Strategy to Combat Human Trafficking 2019-2024 (Public Safety Canada 2019) establishing a national

Section 286.1 for the first time criminalizes purchasing sexual services from an adult. Section 286.4 newly criminalizes knowingly advertising sexual services. The PCEPA replaces a constitutionally impugned "living on the avails" offence with receiving a material benefit (section 286.2) and re-enacts a procuring offence (section 286.3). The commodification offences are categorized as "offences against the person and reputation" and are now considered to be violent offences for statistical purposes. The PCEPA re-criminalizes publicly selling sexual services in at least two circumstances: offering, providing, or purchasing sexual services that stops or impedes traffic or takes place in a place where children are likely to be present as summary conviction offences (section 213(1)). Selling sexual services may also be criminalized in some circumstances under the procuring and receiving a material benefit offences (Sterling and van der Meulen 2018). For various critiques, see, e.g., Bruckert 2015; Davies 2015; Durisin, van der Meulen and Bruckert 2018; Galbally 2016.

6 The new PCEPA commodification offences have mandatory fines as the only available punishment for purchasing adult sexual services, presumably based on a gendered assumption that most-if not all-purchasers are cisgender, straight men who have the economic capacity to pay a fine.

7 We acknowledge and thank our first anonymous reviewer for expressing this insight so clearly and have used some of the suggested phrasing here. We are profoundly grateful to both reviewers whose comments substantially improved our manuscript. 
human trafficking hotline and a national advisor on human trafficking; national government consultations and reports on trafficking in persons; anti-trafficking law enforcement units that originally were embedded in vice and counterexploitation units; government and non-government anti-trafficking campaigns; and in the mediatization of trafficking cases.

Of concern, the legislative conflation and expansion of criminal laws to regulate the commercial sex sector and sex trafficking stand in addition to an immigration regulation introduced in 2012, Protecting Workers from Abuse and Exploitation, designed to prevent the migration of and/or to deport foreign nationals. This regulation is directed especially at women and girls between the ages of fifteen and twenty-one suspected of coming to Canada on temporary visas to work in the commercial sex sector, broadly defined, on the pretext of the state benevolently "protecting" such young women from exploitation. There is some preliminary data suggesting that this regulation is being used to racially profile women (Daly 2017). This legislative expansionism and convergence of criminal and immigration laws, so-called "crimmigration," to regulate commercial sex work are reinforced and augmented by a variety of other laws (family laws, municipal bylaws, residential tenancy laws, and taxation laws) that are also being used to punitively regulate those who work in the commercial sex sector (see, Chu, Clamen, and Santini 2019).

Legislative expansionism is further accompanied by increased surveillance of "at-risk" communities through "preventive" policing-especially police undercover operations and workplace raid and rescue campaigns-with questionable empirical evidence about the effectiveness of these campaigns ${ }^{8}$ and, frequently, adverse consequences for members of communities who are subject to intensified and unwarranted legal intervention (see, e.g., Belak and Bennet 2016; Belak et al. 2016; Benoit, Jansson, Smith, and Flagg 2017; Butterfly Asian and Migrant Sex Workers Support Network 2018; Canadian Alliance for Sex Work Law Reform (CASWLR) and Pivot Legal Society 2016; Canadian HIV/AIDS Legal Network 2018; Canadian Public Health Association 2014; Clancey, Khushrushahi and Ham 2014; Global Network of Sex Work Projects (NSWP) 2018; Khan 2015; Krüsi Pacey, et al. 2014; Lam 2016, 2018; Platt et al. 2018; Sterling and Van der Meulen 2018).

\section{Methods}

In our original 2015 study, we examined the introduction and enforcement of Canadian anti-trafficking laws from 2001 to 2014. Among our findings, we documented concerns about inadequate empirical evidence for the creation and

8 Police agencies frequently publish their own data via the mainstream and social media, typically indicating that only a few minors or exploited persons are actually "rescued" despite interviewing often hundreds of sex workers. These same agencies also note an unwillingness of most sex workers to cooperate with police, while failing to recognize the many reasons why, other than a concern for third-party retaliation. Other reasons may include a lack of trust in the police and the criminal justice system; the persistent stigmatization of sex workers, frequently treated as non-ideal victims and disbelieved when reporting crimes to the police; and individual and structural violence directed by the police and other law enforcement agencies against Indigenous, Black, and other racialized and gendered communities, including sex workers, migrants, asylum seekers, and refugees (see, e.g., Bruckert and Hannem 2013; Burke 2018; Krüsi, Kerr, et al. 2016; Lam and Lepp 2019; Maynard 2017, 2018). 
amendment of these laws; the conflation of human trafficking with commercial sex work, where sex work is viewed as inherently violent and exploitive; the misrepresentation, especially exaggerated claims, of human trafficking cases by the media, government agencies and non-government organizations; the heteronormative and gendered (binary) nature of prosecuted accused and their alleged victims ${ }^{9}$; and the apparent sensationalistic and racialized media coverage of human trafficking arrests and prosecutions. Since our initial report, we have undertaken to verify subsequent prosecuted trafficking cases and to more systematically examine the sensationalistic, gendered and racialized dimensions of the aggregate eighty-seven prosecuted cases (2001 to 2018). We include an additional forty prosecuted prostitution and commodification cases (2015 to 2018) for comparative analysis. Additionally, we incorporate Statistics Canada gender-disaggregated policereported crime data to illustrate the changing and gendered dimensions of police charging practices for trafficking, prostitution and commodification offences. ${ }^{10}$

Without government-reported ethnoracial disaggregated crime and criminal court data, and given that we were not employing a method whereby we could ask participants to self-identify their race or ethnicity, we visually and textually examined mainstream (mainly) print media coverage, especially the use and non-use of photographic images of accused and the associated headlines and news stories. ${ }^{11}$ We additionally examined the published (reported) court proceedings for textual references to an accused or victim's citizenship status, country of origin, and/or ethnoracial identity. In reported court proceedings, we expected references to citizenship status and country of origin or ethnoracial identity if the accused or the victim were facing potential immigration consequences, especially in transborder trafficking cases. We anticipated that ethnoracial identity might be referenced if the accused was Indigenous or Black because of Gladue and cultural impact assessment reports that seek to address historic and contemporary structural disadvantage and systemic racism in the criminal justice system. In view of the claimed overrepresentation of Indigenous women and girls as trafficking victims (see, e.g., Public Safety Canada 2012; Royal Canadian Mounted Police (RCMP) 2010, 2014), we anticipated references to the Indigeneity of victims as an aggravating factor in sentencing. Because criminal courts can prohibit the publication of the identity of sexual violence victims and now uniformly apply publication bans in trafficking cases, identifying victims by initials only, we relied on media published

9 For simplicity, we use the term "victim" to refer to both alleged victims (complainants) and cases involving a legal finding that a victim was trafficked.

10 The police-reported crime statistics are publicly accessible via Statistics Canada (CANSIM). We also requisitioned gender-disaggregated data for charged adults and youths (data on file with the authors).

11 Our media analysis involved an Internet search for news stories and images for all cases with a named suspect and a self-disclosed victim. We searched both English- and French-language sources, focusing on mainstream print media and some video coverage from national news outlets (such as the Canadian Broadcasting Corporation, Canadian Television Network, Global News Network), and local news outlets and newspapers (such as the Montreal Gazette, Toronto Star, the Ottawa Citizen, the Hamilton Spectator, the Vancouver Sun, the Calgary Herald, and the Chronicle Herald). We also used police social media sources like Facebook and Twitter. Our media analysis is preliminary; a more rigorous analysis of mediatization, especially on the symbiotic or working relationships between the mainstream media and law enforcement agencies, is needed. 
photos of victims who have voluntarily self-identified as being trafficked and publicly disclosed their victimization. We also relied on the associated victim imagery the media used in relation to the named criminal accused across the 127 trafficking, commodification, and prostitution cases.

As with all such research, there are limitations associated with our data sets and analysis, especially our visual as opposed to self-identification of ethnoracial identity. Methodologically in line with others who engage in similar work (Roots 2018), ${ }^{12}$ we present our findings as tentative, yet compelling data. Our data raises questions about the perceived racialization and sensationalism used by the media and the police, who often actively seek press coverage of their arrests and charges in anti-prostitution and anti-trafficking enforcement campaigns and/or who provide suspect photos and information to the media. While there may be alternative interpretations of these data, when viewed in relation to emerging empirical research elsewhere, this data points to the alarming and structurally embedded targeting of racialized persons for criminalization under domestic anti-trafficking laws.

Given recently released human rights and independent academic reports and human rights tribunal decisions documenting racial profiling, systemic bias, and structural violence by Canadian police and the Canadian criminal justice system (see, e.g., Campbell v Vancouver Police Board No 4 2019; National Inquiry into Missing and Murdered Indigenous Women and Girls 2019; OHRC 2018; Commission des droits de la personne et des droits de la jeunesse (Québec) 2011; Tulloch 2018; Wortley 2019), we offer what we believe is a timely and important contribution. We are vitally concerned about sustained perceptions and experiences of individual and systemic racism and structural and other forms of violence directed against Indigenous, Black and other persons of colour, either as criminal suspects or as victims, especially missing and murdered Indigenous women and girls, Black and other sex workers of colour, and persons who lack citizenship status (Amnesty International 2004; CASWLR and Pivot Legal Society 2016; Human Rights Watch 2013, 2017; Inter-American Commission on Human Rights 2014; Lam 2018; Maynard 2016, 2017; Native Women's Association of Canada 2013; Oppal 2012; UN Special Rapporteur on the Rights of Indigenous Peoples 2014; UN Special Rapporteur on Violence against Women, its Causes and Consequences 2018).

\section{Key Findings: A Villain/Victim/Rescuer Narrative}

Paralleling Canada's changed legal landscape for regulating commercial sex, we found that police-reported prostitution charges under the constitutionally impugned provisions of the Criminal Code sharply declined coinciding with the Bedford (2007 to 2013) legal challenge. They are gradually being replaced by charges for trafficking in persons and the new commodification and amended prostitution offence, which have progressively increased. Police-reported charges reveal that a total of 937 persons were charged in relation to an alleged 1,188

12 Roots (2018) used similar methods for analyzing Ontario cases. In view of case overlap, we relied on Roots' (2018, 370-376) identification of the ethnoracial identity for three accused where Roots either observed the court proceedings or had access to court records that we were unable to access. 
incidents of trafficking in persons between 2006 and 2017, with over three quarters of these persons being charged in the last four years (2014 to 2017). Most of these persons were adults ( 883 or $94 \%$ ) and male ( 770 or $82 \%)$. The two most populous provinces (Ontario and Quebec) account for approximately $85 \%$ of those charged. We suspect that this provincial concentration of charges reflect differing police agency priorities and the resources these provinces are investing in anti-trafficking efforts (e.g., the Ontario Strategy to End Human Trafficking 2016-2019). ${ }^{13}$ Even though trafficking incidents and the number of persons charged have steadily increased since 2010, it is important to contextualize that trafficking in persons continues to account for a very small proportion of criminal activity; for example $0.02 \%$ of all criminal incidents reported to the police in 2016 (Ibrahim 2018).

In comparison to these 937 charged persons, we were able to verify 87 trafficking in persons cases actually prosecuted, with several involving multiple co-accused, for roughly the same period. Just under half (48.8\%) of these cases resulted in trafficking specific convictions contrary to section 118 of the Immigration and Refugee Protection Act or section 279.01-279.04 of the Criminal Code. The prosecuted cases overwhelmingly reflect domestic sex trafficking charges (eighty of eighty-seven cases or 92\%). Virtually all the prosecuted cases involved multicount indictments, and a large proportion included co-charges for prostitution and/or commodification offences (sixty-seven cases or $77 \%$ ). A similar proportion (sixty-eight cases or 78\%) involved co-charges for other violence offences, suggesting the prosecuted cases likely represent the most serious offences. Many of the cases involved one or more minor victims consistent with other research suggesting that the enforcement of anti-trafficking laws in Canada (Kaye 2017; Roots 2013) and the United States (Williamson and Marcus 2017) is conflated with the commercial sexual exploitation of children. Most of the prosecuted trafficking cases were prosecuted in Ontario (sixty-three cases) and Quebec (eight cases).

In contrast to Statistics Canada (Ibrahim 2018) police-reported crime data indicating one third of human trafficking incidences are transborder offences involving violations of the Immigration and Refugee Protection Act (IRPA), only six $(7 \%)$ of the prosecuted cases involved alleged transnational trafficking: one case involving alleged sex trafficking and five cases involving alleged labour trafficking concerning the construction and domestic work sectors. One additional case involved alleged trafficking concerning an arranged transnational marriage. Only one of these transborder cases resulted in trafficking specific convictions, with all other cases resulting in either a full or partial acquittal or withdrawal of the trafficking specific charges. As we found with our original study, there continues to be negligible evidence of organized criminal involvement in the post-2015 prosecuted cases.

In brief, we observed racialization and sensationalism across various binary identities that seemed to connote difference and belonging in terms of racially and/or gender-threatening perpetrators, deserving victims, and valiant rescuers.

13 The regional concentration of trafficking charges in Ontario and Quebec varies from prostitutionrelated and commodification charges, which are more widely dispersed across five provinces: Ontario, Quebec, Alberta, Saskatchewan, and Manitoba. These regional variations warrant further investigation. 
These binaries included: cisgender/transgender or gender non-binary, heterosexual/queer, citizen/non-citizen or immigrant to Canada and various ethnoracial distinctions where perpetrators and victims were racialized by their visible identity or surname as either White/Black, Indigenous/non-Indigenous, or Western European versus persons of Eastern European, Caribbean/Central/South American, African, or East/Southeast/South/West Asian, Arab or Muslim descent. We were struck by the apparent overrepresentation of Black male and Caribbean accused as primary or co-accused in at least thirty-five (40\%) of the eighty-seven cases. This percentage is markedly higher than the $3.5 \%$ of Canadians who selfidentify as Black (Statistics Canada 2017), similar to data from the United States collected by Williamson and Marcus, who assert that anti-trafficking law enforcement has become another form of "Black criminalization." These American scholars determined that the use of trafficking charges in place of previous prostitutionrelated charges has resulted in much harsher sentences for essentially the same conduct $(2017,178)$. The impacts are felt at an amplified level for Black men due to preconceived notions of the "pimp" figure and the sustained positioning of sex workers, who are presumed female, lacking agency and requiring state protection. ${ }^{14}$

Like Williamson and Marcus (2017), we found that a disproportionate number (twenty-seven of forty-five) of the published photos in media sources portrayed Black male accused whose photos were often displayed in ways that suggested the accused was threatening (labelled dangerous) or callous (for example, smiling when leaving court). In these same cases, the media frequently headlined the case as a pimping or violence case. We also observed a strategy of "media saturation," where the photos of Black male accused were repeatedly displayed across various news articles, while the same did not seem to apply to the photos of White male accused. In at least two cases where the media published photos of Black accused, the media appeared to mislead the public, since the news article was about a particular accused, yet the photo was of another Black male suspect. Additionally, there seemed to be conspicuous inter-racial patterns in the publication of accused photos. For example, if the media published a photo of a White accused, it was often published in tandem with the photo of a Black co-accused or the news article was hyper-linked to the photo of a Black accused in another unrelated case. Assuming that a significant proportion of the accused should be White in relation to actual population representation (about 73\% according to Statistics Canada 2017 reporting on the 2016 census), the media published very few photos of White male accused, although the same did not seem to apply to White female accused. ${ }^{15}$ These patterns accord with what Maynard $(2017,10)$ describes as anti-Blackness and the

14 See Roots (2018) on the origins of the "Black male pimp" in Canadian legal culture. Notably, human trafficking law enforcement as a part of Black criminalization is simply one manifestation of a broader Western cultural trend of associating crime and danger with Blackness and Black men (see, e.g., Alexander 2012; Hall et al. 1978).

15 We found that the media published photos for thirteen of twenty-one cases involving female accused either as a primary or co-accused, almost all (eleven of thirteen) of whom appeared to be visibly White. We surmise this disparity may be because it is easier to generate (and sell) sensationalistic headlines in statistically rarer cases or because of the presumed gender-nonconformity of female accused who allegedly traffic other females. 
"encoding of Black persons as criminal, dangerous and unwanted ... across Canadian institutions."

In addition to the racialized photo imagery, we observed that at least twenty of the prosecuted cases appeared to involve male and female accused with racialized (especially Arab/Muslim and Eastern European) names, and in at least one case, the presumed Muslim faith of the accused was the main news headline (Cueni-Cohen 2018). Cumulatively, these patterns suggest the media use racialized and gendered stereotypes in framing their coverage of criminally accused and offences, which aligns with a racial threat hypothesis. The disproportionate number of Black accused and accused with Arab/Muslim names represented among these eighty-seven cases calls into question whether racialized accused are actually committing a greater proportion of trafficking offences (arguably due to deeply embedded structural disadvantage and social alienation resulting from widespread discrimination and social exclusion across multiple social, political, and economic institutions) or are being racially profiled by the police and those with prosecutorial discretion.

These findings, while tentative, accord with other empirical research on antitrafficking law enforcement in Ontario (Roots 2018). The findings are significant as well given that most of the prosecuted cases are from Ontario and Quebec, where recent investigations and judgments have ascertained the existence of racial profiling, systemic racism and structural violence within the criminal justice system. This data highlight a number of potentially adverse legal consequences associated with racialized and gendered sensationalism, including jeopardizing an accused's right to a fair trial, especially when the police provide misleading suspect photos to the press and/or hold press conferences and make inflammatory and possibly false or inaccurate statements about an accused (see, e.g., $R$ v Joseph 2018; Ladha, Mumtaz et al. $v$ Canada (Attorney General) and BC (R) 2015; Russell and Robinson 2019). ${ }^{16}$

By way of comparison, we found that, with the forty prostitution and commodification cases, the media seemed more inclined to publish a photo of a White male accused in cases involving the purchase of sex from a minor and/or co-charges pertaining to the (predatory) sexual exploitation of children. Conversely, the photos of Black male accused were more likely to be published in procuring and material benefit cases, again reflecting and reinforcing binary racialized stereotypes. We also observed that sex purchasing cases appeared to receive far less media attention than alleged human trafficking and pimping cases.

16 The prosecuted cases suggest several possible negative legal consequences when the media and/or police make sensationalized (inflammatory) and/or misleading claims about accused, including potentially jeopardizing an accused's constitutional right to a fair trial, change of venue requests due to adverse publicity, and tortious claims by defendants for defamation, malicious prosecution, and negligent publication. There are also potential litigation consequences concerning infringed equality rights and rights to non-discrimination based on recognized prohibited grounds under international law and the Canadian Charter of Rights and Freedoms and federal and provincial/ territorial human rights laws. For example, the Ladha case received enormous media attention within Canada and internationally. Ladha was portrayed by the RCMP and the media as "enslaving" a young Tanzanian woman as her domestic helper. Ladha was acquitted of all charges and successfully pursued a civil lawsuit resulting in an out-of-court settlement that included an apology from the RCMP and the BC government for their "relentless" efforts to seize her assets and for their aggressive public narrative of the alleged enslavement (Jeong 2017; Ladha, Mumtaz et al. $v$ Canada (Attorney General) and BC (R). 2015). 
In sharp contrast to the media portrayal of racially threatening human traffickers, the media portrayal of human trafficking victims overwhelmingly suggests that the victims are sympathetic/unwitting young White females in need of rescue by a benevolent and predominantly White criminal justice system, White victim advocates or religious institutions (such as the Salvation Army and a variety of Protestant and Catholic churches and charities). ${ }^{17}$ While the identity of victims is protected in prosecuted trafficking cases, some victims or their families have come forward to the media, once again imparting an image that most victims of trafficking are young White-appearing women. ${ }^{18}$ Moreover, the media portrayal of many of the eighty-seven prosecuted cases used inter-racial White victim imagery juxtaposed with the photo of a Black accused or an alleged trafficker with a Muslim/Arab surname, especially images of White hands bound in ropes or chains, sometimes controlled by Brown hands, or a White victim who is otherwise physically constrained. ${ }^{19}$ General media coverage of human trafficking cases also seems to use these same stock images of, for example, a young White female whose face is not shown, or who is branded, or White street-based sex workers (even though street sex work is known to be highly racialized and despite the fact that most of the prosecuted cases related to trafficking involving indoor sex work). ${ }^{20}$ In other cases, photos or images of the criminal justice system were used, usually of White police officers or Crown counsel or victim advocates or photos or images of court houses, the scales of justice, police cars, or the logos of police forces. ${ }^{21}$

In relation to the changed post-PCEPA law enforcement landscape, the police -and other law enforcement agencies, including border enforcement and bylaw authorities-have changed their policing tactics by implementing proactive suppression campaigns that are strategically packaged for and by the media through press conferences as "rescuing" vulnerable young women and girls from exploitation (being forced into the sex trade or perceived to be at risk of trafficking). These operations include the RCMP's Canada-wide multi-agency "Northern Spotlight," now in its seventh iteration (RCMP 2018), York Regional Police's "Project Raphael" (York Regional Police 2017), and Peel Regional Police's "Rescue Innocence" (Mullins 2011), where the media have readily reported the statistics and information provided to them by the police, despite the inaccuracy of some of that information ( $R v$ Joseph 2018). A number of these and other operations have

17 This pattern is a part of a broader historical tradition of moral crusades targeting "White slavery" (see, especially, Nagel 2015).

18 Selected examples include Markie Dell, whose photo and story were published and republished for the better part of a year, Timea Nagy, Debbie Cumby, Simone Bell, Jasmine Scott, and Maddison Fraser, who is deceased but whose family came forward to identify her in the media as a trafficking victim. In most of these cases, the alleged trafficker is not named so it is not possible to ascertain whether they were charged, prosecuted, or convicted of a trafficking offence.

19 See, for example, the Toronto Star series, "Beaten, Branded, Bought and Sold" http://projects. thestar.com/human-sex-trafficking-ontario-canada/, which profiles fifteen persons accused of human trafficking, eleven of whom are visibly Black men, and six alleged trafficking victims, four of whom appear to be White.

See, e.g., "Girl in a Dirty Box" https://globalnews.ca/news/4314916/25-of-human-trafficking-vic tims-in-canada-are-children-statscan/ (The Canadian Press 2018).

21 See, e.g., "Teen Pimps Plead Guilty in Human Trafficking Case” https://lfpress.com/news/localnews/teen-pimps-plead-guilty-in-human-trafficking-case (Sims 2018). 
specifically targeted sex purchasers through police sting operations, such as Cape Breton Regional Police's “Operation John Be Gone” (Cape Breton Post 2018) and various other city police sting operations (Montreal, London, Toronto, York, Edmonton, and Vancouver), where, in some instances, the media have published the names, ages, and community of residence of the alleged purchasers (but inconsistently not their photos) in an effort to publicly shame them and deter other potential purchasers (Judd 2019).

As the prosecuted cases affirm, these police tactics raise complex legal questions about the defence of entrapment and a suspect's right to a fair trial, particularly in cases involving significant adverse, and in some cases inaccurate or misleading, publicity. A number of these police operations and their associated press conferences have been actively opposed by sex workers and sex worker rights organizations, who question the efficacy of the campaigns and note their negative impacts (see, e.g., The Canadian Press 2018; Ling 2018; Pivot Legal Society 2017). In addition to adversely affecting the right of sex workers to seek a livelihood (it is generally legal for an adult to sell sex in Canada unless doing so publicly in a manner that impedes traffic or is in close proximity to a place where children are likely to be present), these campaigns jeopardize the health, safety, and wellbeing of sex workers, including migrant sex workers who have been detained and summarily deported (Burke 2018; Chu, Clamen, and Santini 2019; Lam 2018). Indeed, there is emerging empirical evidence that these racializing stereotypes, when combined with the criminalization of commercial sex work, contribute to greater fear and vulnerability for racialized sex workers, who are forced to take fewer precautions in negotiating with clients (Sterling and van der Meulen 2018). ${ }^{22}$

The dominance of inter-racialized images of Black and Arab/Muslim accused and White female victims is highly problematic, not only in terms of which suspects are likely to be over-surveilled by police and disproportionately prosecuted and convicted, but also because it influences which victims have access to justice. Our findings add to the existing literature suggesting there are racialized victim hierarchies in Canada (Chan and Chunn 2014; Jiwani 2009, 2019; Raguparan 2019). For example, there has been considerably less media coverage of transborder trafficking victims, such as the fate of the nineteen male victims and their families in the high-profile Domotor-Kolompar Ontario labour-trafficking case. It is also clear from the limited available Canadian data that Indigenous and Black women and girls are targeted for violence at a higher rate than White women and girls (see, e.g., Native Women's Association of Canada 2013) ${ }^{23}$ and still seem to be vastly underrepresented in much of the media coverage and in the 127 prosecuted cases. Despite repeated claims by the police and others that trafficking is strongly linked to violence against Indigenous women and girls, Indigenous victims were judicially

22 Again, this observation is merely one example of broader systemic discrimination that occurs in intersecting ways. See Crenshaw (1991) for a fulsome discussion of intersectionality and access to justice.

23 See especially O'Doherty and Waters (2019), regarding the differential gender-based impacts of criminalization on sex workers generally, and Burke (2018), on the intersecting effects of citizenship, gender, and sex work. 
identified in only two trafficking cases and two commodification cases, representing a total of ten victims across the 127 cases. Further, judicial proceedings rarely identified Black female victims (only two or three cases). Due to many factors, including low reporting rates and a justifiable lack of confidence in the Canadian colonial state, these data once again demonstrate the invisibility of the violence done to Indigenous and Black women and girls, and other persons of colour (see, especially, Hunt 2015; Jiwani 2019; Kaye 2017; Martin and Walia 2019; Maynard 2017, 2018; Raguparan 2019; UN Special Rapporteur on the Rights of Indigenous Peoples 2014). Likewise, the reductive narrative of human trafficking as sex trafficking means that labour and human rights violations, other forms of exploitation, and forced labour in multiple (and especially precarious) work sectors remain invisible and unaddressed (Millar and O’Doherty 2015).

\section{Conclusion and Recommendations}

Our data offer some qualified empirical support that anti-trafficking and antiprostitution laws are being enforced and publicized along racialized, gendered, and sensationalistic lines in a context of over-surveilling some populations while underprotecting other groups (particularly Indigenous, Black and other racialized persons, migrants, same-sex and gender non-binary sex workers). This finding is consistent with other critical anti-trafficking scholarship in Canada (see, e.g., Burke 2018; Chu, Clamen, and Santini 2019; Hunt 2015; Kaye 2017; Kempadoo et al. 2017; Lam 2018; Maynard 2017; Roots 2018) and in other countries (see, e.g., Faulkner 2018; Kempadoo 2016; Kinney 2015; O’Brien 2016; Shih 2016; Soderlund 2005; Srikantiah 2007). It is also consistent with more general criticisms of media outlets, such as the Toronto Star, for their overt racialization of news reports naming the race of Black suspects while not naming the race of White suspects who are wanted by the police (English 2016), and broader critical race analyses of the mainstream media (e.g., Jiwani 2009; Tator and Henry 2000).

It remains deeply troubling that, in the twenty-first century, the mainstream media and the criminal justice system in Canada appear to operate on and perpetuate racialized and gendered perpetrator and victim myths, stereotypes, and hierarchies. Perceptions and experiences of racial—alongside gender, sexuality, economic, citizenship, and occupational-bias have significant adverse consequences, especially for the dignity, equality, liberty, security, mobility, labour, and access-to-justice rights of Indigenous, Black, and other racialized and historically marginalized communities who are simultaneously over and under policed and prosecuted. Such perceptions and experiences contribute to a profound sense of distrust by these same communities in the Canadian criminal justice system (see, e.g., Kaye 2017; Martin and Walia 2019; Maynard 2017) and potentially infringe an array of internationally and domestically protected legal and human rights, including, at a minimum, the right to a fair trial, liberty and personal security rights, equality rights, and rights of non-discrimination. Such media depictions are known to influence community perceptions, especially of race and crime (English 2016), and policymakers and public policy, extending to funding for non-government and community-based organizations (see, e.g., De Shalit, Heynen, and van der Meulen 2014). 
Accordingly, we join various other critical race and feminist scholars, activists, and legal and human rights entities in calling on Canada to collect and publish racedisaggregated crime and victimization data so that all stages of criminal justice decision-making can be properly scrutinized and challenged (see, e.g., African Canadian Legal Clinic 2017; Owusu-Bempah and Wortley 2014; Reasons et al. 2016; UN Committee on the Elimination of Racial Discrimination. 2017; UN Working Group on Persons of African Descent 2016/2017). We also support other recommendations to address ongoing individual and systemic-especially antiBlack, anti-Indigenous, and anti-Muslim-racism in Canada, for example by enacting explicit anti-racism laws like the Ontario Anti-Racism Act (2017). Further, we join recommendations that all Canadian institutions, including the media, the police, the prosecution service and the judiciary, be demographically diverse and representative; that Canada research and address the root structural causes of the disproportionate victimization and criminalization of Indigenous, Black, and other racialized communities; that Canada fully implement the recommendations of international bodies and national and provincial/territorial commissions of inquiry, especially those on systemic racism and racial profiling, truth and reconciliation, and missing and murdered Indigenous women and girls; and that Canada (and the provinces/territories) mandate unconscious bias and locally-specific cultural competency training for all those who work in the media and the criminal justice system.

As a matter of law, the media and the police have an obligation to ensure they provide factually accurate and unbiased information to the public and they-along with the Canadian state-must be held accountable for demonizing and rendering invisible or disposable the members of Indigenous, Black, and other racialized and marginalized communities. Moreover, as was done in the Bedford legal challenge, we suggest the enhanced use of social science empirical evidence and/or experts in criminal trial processes to challenge highly problematic, racist, gender-biased, heteronormative, misogynist, and essentialist stereotypes about the commercial sex sector and its participants, while recognizing the complexities of expert evidence in criminal and constitutional litigation (Lowman 2016). More generally, we support Indigenous decolonization and Black liberation movements and an ever-growing body of international and Canadian experiential persons, activists, academics, and human rights and health organizations calling for the decriminalization and destigmatization of sex work and the full extension of human and labour rights to sex workers.

\section{References}

African Canadian Legal Clinic. 2017. Report of the African Canadian Legal Clinic ("ACLC") to the United Nations Human Rights Council Universal Periodic Review of Canada 3rd Cycle (May 2018) October 2017. Toronto.

Amnesty International. 2004. Stolen Sisters: A human rights response to discrimination and violence against indigenous women in Canada. London: Amnesty International Secretariat.

Alexander, Michelle. 2012. The New Jim Crow: Mass incarceration in the age of colorblindness. New York: The New Press.

Bahdi, Reem. 2003. No Exit: Racial profiling and Canada's war against terrorism. Osgoode Hall Law Journal 41, no. 2/3: 293-317. 
Balgamwalla, Sabrina. 2016. Trafficking in Narratives: Conceptualizing and recasting victims, offenders, and rescuers in the war on human trafficking. Denver Law Review 94: $1-41$.

Belak, Brenda, and Darcie Bennett. 2016. Evaluating Canada's Sex Work Laws: The case for repeal. Vancouver: Pivot Legal Society. http://www.pivotlegal.org/evaluating_canada_ s_sex_work_laws_the_case_for_repeal

Belak, Brenda, Raven Bowen, Kerry Porth, Kate Shannon, and Matthew Taylor. 2016. Position Paper: Sex Work Law Reform: Implications for male sex workers in Vancouver and beyond. Vancouver: Health Initiative for Men. https://checkhimout.ca/wp-con tent/uploads/2013/07/HIM-Position-Paper-Sex-Work-Law-Reform_2016-11.pdf

Benoit, Cecelia, Mikael Jansson, Michaela Smith, and Jackson Flagg. 2017. "Well, It Should Be Changed for One, Because It's Our Bodies": Sex Workers' Views on Canada's Punitive Approach towards Sex Work. Social Sciences 6, no. 2: 52-69.

Bernstein, Elizabeth. 2010. Militarized Humanitarianism Meets Carceral Feminism: The politics of sex, rights, and freedom in contemporary anti-trafficking campaigns. Signs: Journal of Women in Culture and Society 36, no. 1: 45-71.

British Columbia Civil Liberties Association (BCCLA). 2010. Racial Profiling: A Special Report on Racial Profiling in Canada. Vancouver, BC: BCCLA. https://bccla.org/wpcontent/uploads/2012/03/2007-BCCLA-Report-Racial-Profiling.pdf

Bruckert, Chris. 2015. Protection of Communities and Exploited Persons Act: Misogynistic law making in action. Canadian Journal of Law and Society 30, no. 1: 1-3.

Bruckert, Chris, and Stacey Hannem. 2013. Rethinking the Prostitution Debates: Transcending structural stigma in systemic responses to sex work. Canadian Journal of Law and Society 28, no. 1: 43-63.

Burke, Nora Butler. 2018. Double Punishment: Immigration penality and migrant trans women who sell sex. In Red Light Labour: Sex Work Regulation, Agency and Resistance, ed. Elya Durisin, Emily van der Meulen, and Chris Bruckert, 203-212. Vancouver: UBC Press.

Butterfly Asian and Migrant Sex Workers Support Network. 2018. Brief to the House of Commons Standing Committee on Justice and Human Rights on Human Trafficking in Canada: How migrant sex workers are harmed by anti-trafficking initiatives and policies. Ottawa: House of Commons Standing Committee on Justice and Human Rights, National Consultation on Human Trafficking in Canada. https://www.ourcommons.ca/Content/ Committee/421/JUST/Brief/BR10005482/br-external/ButterflyAsianAndMigrantSexWor kersSupportNetwork-e.pdf

Canadian Alliance for Sex Work Law Reform (CASWLR) and Pivot Legal Society. 2016. Joint Submission for Canada's Review before the UN Committee on the Elimination of All Forms of Discrimination against Women, 65th Session. Geneva: Committee on the Elimination of All Forms of Discrimination against Women. https://tbinternet.ohchr. org/Treaties/CEDAW/Shared\%20Documents/CAN/INT_CEDAW_NGO_CAN_ 25385_E.pdf

Canadian HIV/AIDS Legal Network. 2018. Brief to the House of Commons Standing Committee on Justice and Human Rights on Human Trafficking in Canada. Ottawa: House of Commons Standing Committee on Justice and Human Rights, National Consultation on Human Trafficking in Canada. https://www.ourcommons.ca/Content/Committee/421/ JUST/Brief/BR10002954/br-external/CanadianHIVAIDSLegalNetwork-e.pdf

(The) Canadian Press. 2018. 25\% of human trafficking victims in Canada are children: StatsCan. Global News, 5 July. https://globalnews.ca/news/4314916/25-of-human-traf ficking-victims-in-canada-are-children-statscan/ 
38 Hayli Millar and Tamara O’Doherty

Canadian Public Health Association. 2014. Position Paper. Sex Work in Canada: The public health perspective. Ottawa: Canadian Public Health Association.

Cape Breton Post. 2018 (8 August). Exclusive: Cape Breton police complete second prostitution sting. Cape Breton Post. https://www.capebretonpost.com/news/local/exclu sive-cape-breton-police-complete-second-prostitution-sting-232367/

Chan, Wendy, and Dorothy Chunn. 2014. Racialization, Crime, and Criminal Justice in Canada. Toronto: University of Toronto Press.

Chu, Sandra Ka Hon, Jen Clamen, and Tara Santini. 2019. The Perils of "Protection:" Sex workers' experiences of law enforcement in Ontario. Canadian HIV/AIDS Legal Network. http://www.aidslaw.ca/site/the-perils-of-protection/?lang=en

Clancey, Alison, Noushin Khushrushahi, and Julie Ham. 2014. Do Evidence-Based Approaches Alienate Canadian Anti-Trafficking Funders? Anti-Trafficking Review 3: 87-108.

Commission des droits de la personne et des droits de la jeunesse. 2011. Racial Profiling and Systemic Discrimination of Racialized Youth Report of the Consultation on Racial Profiling and Its Consequences. Montréal. http://www.cdpdj.qc.ca/publications/Profil ing_final_EN.pdf

Crenshaw, Kimberlé. 1991. Mapping the Margins: Intersectionality, identity politics and violence against women of colour. Stanford Law Review 43:1241-99.

Cueni-Cohen, Jill. 2018. Two Muslims Convicted of Forcing Women and Girls into Prostitution. DML News, 3 February. https://dmlnews.com/two-muslims-convictedforcing-women-girls-prostitution/

Daly, Rachelle. 2017. Canada's Relationship with Women Migrant Sex Workers: Producing "vulnerable migrant workers" through "protecting workers from abuse and exploitation." Master's thesis, Wilfred Laurier University.

Davies, Jacqueline M. 2015. "The Criminalization of Sexual Commerce in Canada: Context and Concepts for Critical Analysis." The Canadian Journal of Human Sexuality 24, no. 2: 78-91.

De Shalit, Ann, Robert Heynen, and Emily van der Muelen. 2014. Human Trafficking and Media Myths: Federal Funding, Communication Strategies, and Canadian AntiTrafficking Programs. Canadian Journal of Communication 39:385-412.

Doezema, Jo. 2010. Sex Slaves and Discourse Masters: The construction of trafficking. London: Zed Books.

Durisin, Elya M., Emily van der Meulen, and Chris Bruckert (eds.). 2018. Red Light Labour: Sex work regulation, agency, and resistance. Vancouver: UBC Press.

English, Kath. 2016. When Does Star Report Race of Suspects Wanted by the Police: Public editor.” The Star, 30 September. https://www.thestar.com/opinion/public_editor/2016/ 09/30/when-does-star-report-race-of-suspects-wanted-by-police-public-editor.html

Faulkner, Elizabeth A. 2018. The Victim, the Villain and the Rescuer: The trafficking of women and contemporary abolition. The Journal of Law, Social Justice and Global Development (Special Issue on Gender and Development) 21:1-14.

Foster, Lorne, and Les Jacobs. 2017. Why Police Should Collect Racial Data. Canadian Diversity 14, no. 1:16-18.

Foster, Lorne, Les Jacobs, and Bobby Siu. 2016. Race Data and Traffic Stops in Ottawa, 20132015. A Report on Ottawa and the Police Districts Submitted to Ottawa Police Services Board and Ottawa Police Service. https://www.ottawapolice.ca/en/about-us/resources/ .TSRDCP_York_Research_Report.pdf

Galbally, Phoebe J. 2016. Playing The Victim: A critical analysis of Canada's Bill C-36 from an international human rights perspective. Melbourne Journal of International Law 17: $1-35$. 
Gallagher, Anne T. 2010. The International Law of Human Trafficking. Cambridge: Cambridge University Press.

Gittens, Margaret, and David Cole (Co-Chairs). 1995. Report of the Commission on Systemic Racism in the Ontario Criminal Justice System. Toronto: Commission on Systemic Racism in the Ontario Criminal Justice System.

Global Network of Sex Work Projects (NSWP). 2018. Policy Brief: The impact of antitrafficking legislation and initiatives on sex workers. Edinburgh: Global Network of Sex Work Projects. https://www.nswp.org/sites/nswp.org/files/impact_of_anti-traffick ing_laws_pb_nswp_-_2018.pdf

Hall, Stuart, Brian Roberts, John Clarke, Tony Jefferson, Chas Critcher. 1978. Policing the Crisis: Mugging, the state and law and order. London: Palgrave MacMillan.

Human Rights Watch. 2013. Those Who Take Us Away: Abusive policing and failures in protection of indigenous women and girls in Northern British Columbia, Canada. New York: Human Rights Watch. https://www.hrw.org/report/2013/02/13/thosewho-take-us-away/abusive-policing-and-failures-protection-indigenous-women\#

Human Rights Watch. 2017. Submission to the Government of Canada, Police Abuse of Indigenous Women in Saskatchewan and Failures to Protect Indigenous Women from Violence. New York: Human Rights Watch. https://www.hrw.org/sites/default/files/ supporting_resources/canada_saskatchewan_submission_june_2017.pdf

Hunt, Sarah. 2015. Representing Colonial Violence: Trafficking, sex work, and the violence of law. Atlantis: Critical Studies in Gender, Culture and Social Justice 37, no. 2(1): 25-40.

Ibrahim, Dyna. 2018. Trafficking in Persons in Canada, 2016. Juristat Bulletin - Quick Fact. Ottawa: Canadian Centre for Justice Statistics.

Inter-American Commission on Human Rights. 2014. Missing and Murdered Indigenous Women in British Columbia, Canada. Washington, DC: Organization of American States.

Jeong, Jimmy. 2017. B.C. Woman Acquitted of Human Trafficking Settles Case Over Civil Forfeiture. The Globe and Mail, 9 August. https://www.theglobeandmail.com/news/ british-columbia/bc-woman-acquitted-of-human-trafficking-settles-case-over-civilforfeiture/article35933915/

Jiwani, Yasmin. 2009. Report Race and the Media: A retrospective and prospective gaze. Canadian Journal of Communication 34:735-40.

Jiwani, Yasmin. 2016. Mediations of Race and Crime: Racializing crime, criminalizing race. In Diversity, Crime and Justice in Canada (second edition), ed. Barbara Perry, 43-62. Don Mills, Ontario: Oxford University Press.

Jiwani, Yasmin. 2019. Remembering Everyday Violence Against Women and Girls on Dec. 6. The Conversation, 5 December. https://theconversation.com/rememberingeveryday-violence-against-women-and-girls-on-dec-6-128446

Judd, Amy. 2019. 2019. Former Vancouver Private School Teacher, School Trustee among 27 Men Arrested in VPD Sex Sting. Global News, 23 January. https://globalnews.ca/ news/4879364/47-men-arrested-vancouver-sexual-services-youth/

Kaye, Julie. 2017. Responding to Human Trafficking: Dispossession, colonial violence, and resistance among Indigenous and racialized women. Toronto: University of Toronto Press.

Kempadoo, Kamala. 2005. From Moral Panic to Global Justice: Changing perspectives on trafficking. In Trafficking and Prostitution Reconsidered: New perspectives on migration, sex work, and human rights, ed. Kamala Kempadoo, Jyoti Sanghera, and Bandana Pattanaik, vii-xxxiv. Boulder, Colorado: Paradigm Publishers.

Kempadoo, Kamala. 2016. The War on Humans: Antitrafficking in the Caribbean. Social and Economic Studies 65, no. 4: 5-32. 
Kempadoo, Kamala, Nicole McFadyen (coordinators), Phillip Pilon, Andrea Sterling, and Alex Mackenzie. 2017. Challenging Trafficking in Canada: Policy Brief. Toronto: Centre for Feminist Research, York University.

Khan, Ummni. 2015. "Johns" in the Spotlight: Anti-prostitution efforts and the surveillance of clients. Canadian Journal of Law and Society 30, no. 1: 9-29.

Kinney, Edith. 2015. Victims, Villains, and Valiant Rescuers: Unpacking sociolegal constructions of human trafficking and crimmigration in popular culture. In The Illegal Business of Human Trafficking, ed. Maria João Gui, 87-108. New York: Springer.

Krüsi, Andrea, Katrina E. Pacey, Lorna Bird, Jill Chettiar, Sarah Allan, Darcie Bennett, Julio Montaner, Thomas Kerr, and Kate Shannon. 2014. Criminalisation of Clients: Reproducing Vulnerabilities for violence and poor health among street-based sex workers in Canada-A qualitative study. BMJ Open 4, no. 6, e005191.

Krüsi, Andrea, Thomas Kerr, Christina Taylor, Tim Rhodes, and Kate Shannon. 2016. "They Won't Change It Back in Their Heads that We're Trash": The intersection of sex workrelated stigma and evolving policing strategies. Sociology of Health and Illness 38, no. 7: 1137-50.

Lam, Elene. 2016. Inspection, Policing and Racism: How municipal by-laws endanger the lives of Chinese sex workers in Toronto. Canadian Review of Social Policy 75:87-112.

Lam, Elene. 2018. Behind the Rescue: How Anti-Trafficking Investigations and Policies Harm Migrant Sex Workers. Toronto: Butterfly Asian and Migrant Sex Workers Support Network.

Lam, Elene, and Annalee Lepp. 2019. Butterfly: Resisting the harms of anti-trafficking policies and fostering peer-based organising in Canada. Anti-Trafficking Review 12: 91-107.

Lewis, Stephen. 1992. Report on Race Relations in Ontario. Ontario Legislative Assembly. http://www.ontla.on.ca/library/repository/mon/13000/134250.pdf

Ling, Justin. 2018. Governments Have Failed Canada's Sex Workers-And They're Running Out of Patience. Maclean's, 6 September. https://www.macleans.ca/news/canada/gov ernments-have-failed-canadas-sex-workers-and-theyre-running-out-of-patience/

Lowman, John. 2016. The Role of Expert Testimony in Bedford v. Canada and R. v. McPherson. Excerpt from "In the Eye of the Storm: The (Ab)Use of Research in the Canadian Prostitution Law Reform Debate," A paper presented at "Sex Work and Human Rights: Lessons from Canada for the UK," Durham Law School, Durham University, September 18-19, 2014.

Martin, Carol Muree, and Harsha Walia. 2019. Red Women Rising: Indigenous women survivors in Vancouver's downtown eastside. Downtown Eastside Women's Centre. https://mail.sfu.ca/owa/\#path=/attachmentlightbox

Maynard, Robyn. 2016. Fighting Wrongs with Wrongs? How Canadian anti-trafficking crusades have failed sex workers, migrants, and Indigenous communities. Atlantis: Critical Studies in Gender, Culture and Social Justice 37, no. 2(1): 40-56.

Maynard, Robyn. 2017. Policing Black Lives: State Violence in Canada from Slavery to the Present. Halifax: Fernwood Publishing.

Maynard, Robyn. 2018. Do Black Sex Workers' Lives Matter? In Red Light Labour: Sex work regulation, agency and resistance, ed. Elya Durisin, Emily van der Meulen, and Chris Bruckert, 281-92. Vancouver: UBC Press.

McNeilly, Gerry (Independent Police Review Director). 2018. Broken Trust: Indigenous people and the Thunder Bay police service. Systemic Review Report. Toronto: Office of the Independent Police Review Directorate. 
McNeilly, Gerry (Independent Police Review Director). 2019. Breaking the Rule: A review of police strip searches in Ontario. Toronto: Office of the Independent Police Review Directorate.

Millar, Hayli, and Tamara O'Doherty (in collaboration with the SWAN Vancouver Society). 2015. Key Findings: The Palermo Protocol \& Canada: the evolution and human rights impacts of antitrafficking laws in Canada (2002-2015). International Centre for Criminal Law Reform and Criminal Justice Policy.

Millar, Paul, and Akwasi Owusu-Bempah. 2011. Whitewashing Criminal Justice in Canada: Preventing research through data suppression. Canadian Journal of Law and Society 26, no. 3: 653-61.

Monchalin, Lisa. 2010. Canadian Aboriginal Peoples Victimization, Offending and its Prevention: Gathering the evidence. Crime Prevention and Community Safety 12, no. 2: 119-32.

Mosher, Clayton, and Taj Mahon-Haft. 2010. Race, Crime and Criminal Justice in Canada. In Race, Crime and Criminal Justice International Perspectives, ed. Anita KaluntaCrumpton, 242-69. New York: Palgrave Macmillan.

Mullins, K. J. 2011. "Rescue Innocence" Saves People at Risk of Human Trafficking. Digital Journal, 27 April. http://www.digitaljournal.com/article/306063

Nagel, Mechthild. 2015. Trafficking with Abolitionism: An examination of anti-slavery discourses. SSRN Electronic Journal. doi:10.219/ssrn.2649660

Nagra, Baljit, and Paula Maurutto. 2016. Crossing Borders and Managing Racialized Identities: Experiences of security and surveillance among young Canadian Muslims. Canadian Journal of Sociology 41, no. 2: 165-94.

National Inquiry into Missing and Murdered Indigenous Women and Girls. 2019. Reclaiming Power and Place: The Final Report of the National Inquiry into Missing and Murdered Indigenous Women and Girls. Government of Canada. https://www. mmiwg-ffada.ca/final-report/

Native Women's Association of Canada. 2013. List of Reports and Recommendations on Violence against Indigenous Women and Girls. Ottawa: Native Women's Association of Canada. https://www.nwac.ca/wp-content/uploads/2015/05/List-of-Reports-and-Rec ommendations-on-VAIWG.pdf

O'Brien, Erin. 2016. Human Trafficking Heroes and Villains: Representing the problem in anti-trafficking awareness campaigns. Social and Legal Studies 25, no. 2: 205-24.

O’Doherty, Tamara, and Ian Waters. 2019. Gender, Victimization, and Commercial Sex: A comparative study. Atlantis: Critical Studies in Gender, Culture \& Social Justice 40, no. $1: 18-31$.

Ontario Human Rights Commission (OHRC). 2003. Paying the Price: The Human Cost of Racial Profiling Inquiry Report. Toronto: Ontario Human Rights Commission. http:// www.ohrc.on.ca/sites/default/files/attachments/Paying_the_price\%3A_The_human_ cost_of_racial_profiling.pdf

OHRC. 2017. Under Suspicion: Research and Consultation Report on Racial Profiling in Ontario. Toronto: Ontario Human Rights Commission. http://ohrc.on.ca/sites/default/ files/Under\%20suspicion_research\%20and\%20consultation\%20report\%20on\% 20racial\%20profiling\%20in\%20Ontario_2017.pdf

OHRC. 2018. A Collective Impact: Interim Report on the inquiry into Racial Profiling and Racial Discrimination of Black Persons by the Toronto Police Service. Toronto: Ontario Human Rights Commission. http://ohrc.on.ca/sites/default/files/TPS\%20Inquiry_ Interim\%20Report\%20EN\%20FINAL\%20DESIGNED\%20for\%20remed_3_0.

pdf\#overlay-context=en/news_centre/ohrc-interim-report-toronto-police-serviceinquiry-shows-disturbing-results 
Oppal, Wally. 2012. Forsaken: The Report of the Missing Women Commission of Inquiry. Victoria: Missing Women Commission of Inquiry. http://www.missingwomeninquiry. ca/wp-content/uploads/2010/10/Forsaken-ES-web-RGB.pdf

Owusu-Bempah, Akwasi, and Paul Millar. 2010. Research Note: Revisiting the collection of "Justice Statistics by Race" in Canada. Canadian Journal of Law and Society 25, no. 1: 97-104.

Owusu-Bempah, Akwasi, and Scot Wortley. 2014. Race, Crime, and Criminal Justice in Canada. In The Oxford Handbook of Ethnicity, Crime, and Immigration, ed. Sandra Bucerius and Michael Tonry. Oxford: Oxford University Press.

Pivot Legal Society. 2017. Open Letter to BC Police Forces: End participation in Operation Northern Spotlight. Vancouver: Pivot Legal Society. http://www.pivotlegal.org/open letter_to_bc_police_forces_end_participation_in_operation_northern_spotlight

Platt, Lucy, Pippa Grenfell, Rebecca Meiksin, Jocelyn Elmes, Susan G. Sherman, Teela Sanders, Peninah Mwangi, and Anna-Louise Crago. 2018. Associations between Sex Work Laws and Sex Workers' Health: A systematic review and meta-analysis of quantitative and qualitative studies. PLOS Med 15, no. 12: e1002680. https://doi.org/ 10.1371/journal.pmed.1002680

Pratt, Anna, and Sarah K. Thompson. 2008. Chivalry, "Race" and Discretion at the Canadian Border. British Journal of Criminology 48:620-40.

Public Safety Canada. 2012. National Action Plan to Combat Human Trafficking. Ottawa: Public Safety Canada. https://www.publicsafety.gc.ca/cnt/rsrcs/pblctnss/ntnl-ctn-plncmbt/ntnl-ctn-pln-cmbt-eng.pdf

Public Safety Canada. 2019. National Strategy to Combat Human Trafficking 2019-2024. Ottawa: Public Safety Canada. https://www.publicsafety.gc.ca/cnt/rsrcs/pblctns/2019ntnl-strtgy-hmnn-trffc/index-en.aspx

Raguparan, Menaka. 2019. So it's Not Always the Sappy Story": Women of colour and Indigenous women in the indoor sectors of the Canadian sex industry speak out. $\mathrm{PhD}$ diss., Carleton University.

Reasons, Charles, Shereen Hassan, Michael Ma, Lisa Monchalin, Melinda Bige, Christianne Paris, and Simranjit Arora. 2016. Race and Criminal Justice in Canada. International Journal of Criminal Justice Sciences 11, no. 2: 75-99.

Roots, Katrin. 2013. Trafficking or Pimping? An analysis of Canada's human trafficking legislation and its implications. Canadian Journal of Law and Society 28, no 1: 21-41.

Roots, Katrin. 2018. The Human Trafficking Matrix: Law, Policy and Anti-Trafficking Practices in the Canadian Criminal Justice System, PhD diss., York University.

Royal Canadian Mounted Police (RCMP). 2010. Human Trafficking in Canada. Ottawa: Royal Canadian Mounted Police.

RCMP. 2014. Project Safekeeping 2013. Prepared by the Human Trafficking National Coordination Centre. Ottawa: RCMP.

RCMP. 2018. RCMP Operation Northern Spotlight VII: Canadian police services continue to work together to stop human trafficking. Ottawa: RCMP, 24 October. http://www. rcmp-grc.gc.ca/en/news/2018/operation-northern-spotlight-vii-canadian-police-ser vices-continue-work-together-stop

Russell, Andrew, and Megan Robinson. 2019. Ontario Man Files \$7M Lawsuit over 16 "Wrongful" Charges Related to Human Trafficking. Global News, 24 July. https:// globalnews.ca/news/5659860/ontario-man-lawsuit-human-trafficking-charges/

Shih, Elena. 2016. "Not in My "Backyard Abolitionism": Vigilante Rescue against American Sex Trafficking." Sociological Perspectives 59, no. 1: 66-90. 
Sims, Jane. 2018. Teen Pimps Plead Guilty in Human Trafficking Case. London Free Press, 19 June. https://fpress.com/news/local-news/teen-pimps-plead-guilty-in-human-traf ficking-case

Sinclair, Murray (Lead Investigator). 2018. Thunder Bay Police Services Board Investigation Final Report. Submitted to the Safety, Licensing, Appeals and Standard Tribunals Ontario. https://slasto-tsapno.gov.on.ca/ocpc-ccop/wp-content/uploads/sites/5/2018/ 12/TBPSB_Investigation_Final_Report_-_EN-FINAL-1.pdf

Soderlund, Gretchen. 2005. Running from the Rescuers: New U.S. Crusades against sex trafficking and the rhetoric of abolition. National Women's Studies Association Journal 17, no. 3: 64-87.

Srikantiah, Jayashri. 2007. Perfect Victims and Real Survivors: The iconic victim in domestic human trafficking law. Boston University Law Review 87:157-211.

Statistics Canada. 2017. The Daily: Immigration and Ethnocultural Diversity: Key results from the 2016 census, 26 October 2017. Ottawa: Statistics Canada. https://www150. statcan.gc.ca/n1/en/daily-quotidien/171025/dq171025b-eng.pdf?st=YxvRTkgT

Sterling, Andrea, and Emily van der Meulen. 2018. "We Are Not Criminals": Sex work clients in Canada and the constitution of risk knowledge. Canadian Journal of Law and Society 33, no 3: 291-308.

Tanovich, David. 2008. The Charter of Whiteness: Twenty-five years of maintaining racial injustice in the Canadian criminal justice system. Supreme Court Law Review 40: 655-86.

Tator, Carol, and Frances Henry. 2000. The Role and Practice of Racialized Discourse in Culture and Cultural Production. Journal of Canadian Studies 35:120-137.

Tulloch, Michael H (The Honourable). 2018. Report of the Independent Street Checks Review. Queens Printer for Ontario. https://www.mcscs.jus.gov.on.ca/sites/default/files/con tent/mcscs/docs/StreetChecks.pdf

Union of BC Indian Chiefs and BCCLA. 2018. Re: Policy Complaint Concerning Street Checks by the Vancouver Police Department. Letter to the Office of the Police Complaint Commissioner, Victoria, BC. https://bccla.org/wp-content/uploads/2018/06/UBCICBCCLA-OPCC-Complaint-re-Street-Checks-Jun-14-2018-Approved-1.pdf

UN Committee on the Elimination of Racial Discrimination. 2017. Concluding Observations on the Combined Twenty-First to Twenty-Third Periodic Reports of Canada. CERD/C/ CAN/CO/21-23 (13 September 2017).

UN Special Rapporteur on the Rights of Indigenous Peoples. 2014. Report of the Special Rapporteur on the Rights of Indigenous Peoples, James Anaya. Addendum: The situation of indigenous peoples in Canada. Human Rights Council /HRC/27/52/Add.2, 4 July.

UN Special Rapporteur on Violence against Women, Its Causes and Consequences - Official Visit to Canada. 2018. End of Mission Statement by Dubravka Šimonović, United Nations Special Rapporteur on Violence against Women, Its Causes and Consequences - Official visit to Canada, 23 April. https://www.ohchr.org/EN/NewsEvents/Pages/ DisplayNews.aspx?NewsID=22981\&LangID=E

UN Working Group on Persons of African Descent. 2016/2017. Report of the Working Group of Experts on People of African Descent on its Mission to Canada Note by the Secretariat. UN General Assembly A/HRC/36/60/Add.1, 16 August.

Weitzer, Ronald. 2011. The Social Construction of Sex Trafficking: Ideology and institutionalization of a moral crusade. Politics and Society 35, no. 3: 447-75.

Williamson, Kathleen G., and Anthony Marcus. 2017. Black Pimps Matter: Racially selective identification and prosecution of sex trafficking in the United States. In Third Party Sex Work and Pimps in the Age of Anti-Trafficking, ed. Amber Horning and Anthony Marcus. Switzerland: Springer International Publishing. 
44 Hayli Millar and Tamara O’Doherty

Wortley, Scot. 2019. Halifax, Nova Scotia: Street checks report. Nova Scotia Human Rights Commission. https://humanrights.novascotia.ca/sites/default/files/editor-uploads/hali fax_street_checks_report_march_2019_0.pdf

York Regional Police. 2017. Project Raphael. York Regional Police. https://www.yrp.ca/en/ crime-prevention/Project-Raphael.asp

\section{Cases and Legislation}

Anti-Racism Act [Ontario], 2017, S.O. 2017, c.15

Canada (Attorney General) v Bedford, 2013 SCC 72, [2013] 3 S.C.R. 1101

Campbell v Vancouver Police Board (No 4), 2019 BCHRT 275

Ladha, Mumtaz et al. $v$ Canada (Attorney General) and BC (R). 2015. Notice of Civil Claim, British Columbia Supreme Court. https://martinandassociates.ca/wp-content/ uploads/2015/02/Filed-Notice-of-Civil-Claim.pdf

Protection of Communities and Exploited Persons Act, R.S.C. 2014 c. C-46, http://www.parl. $\mathrm{gc.ca} /$ content/hoc/Bills/412/Government/C-36/C-36_1/C-36_1.PDF retrieved on 2015-09-04

$R v$ Barton 2019 SCC 33

$R v$ Le 2019 SCC 34

$R v$ Spence [2005] 3 S.C.R. 458, 2005 SCC 71

$R v$ Williams [1998] 1 S.C.R. 1128

$R v$ Joseph 2018 ONSC 464

Hayli Millar, $\mathrm{PhD}$

Associate Professor

School of Criminology and Criminal Justice

University of the Fraser Valley

hayli.millar@ufv.ca

Tamara O'Doherty, $\mathrm{PhD}$

Lecturer, School of Criminology

Simon Fraser University

tamara_odoherty@sfu.ca 